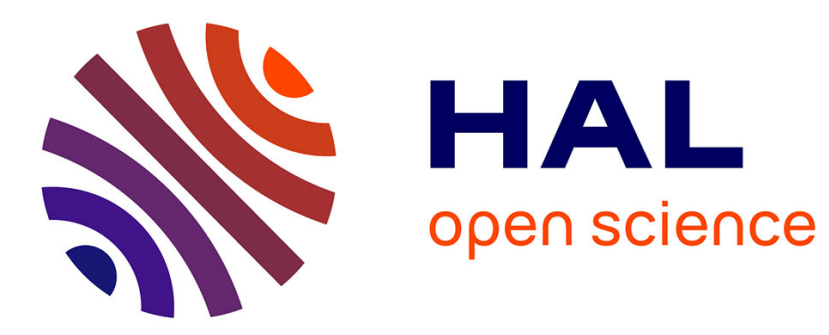

\title{
The composition, supramolecular organisation and thermal properties of milk fat: a new challenge for the quality of food products
}

Christelle Lopez, Valérie Briard-Bion

\section{- To cite this version:}

Christelle Lopez, Valérie Briard-Bion. The composition, supramolecular organisation and thermal properties of milk fat: a new challenge for the quality of food products. Le Lait, 2007, 87 (4-5), pp.317-336. hal-00895653

\section{HAL Id: hal-00895653 \\ https://hal.science/hal-00895653}

Submitted on 1 Jan 2007

HAL is a multi-disciplinary open access archive for the deposit and dissemination of scientific research documents, whether they are published or not. The documents may come from teaching and research institutions in France or abroad, or from public or private research centers.
L'archive ouverte pluridisciplinaire HAL, est destinée au dépôt et à la diffusion de documents scientifiques de niveau recherche, publiés ou non, émanant des établissements d'enseignement et de recherche français ou étrangers, des laboratoires publics ou privés. 


\title{
The composition, supramolecular organisation and thermal properties of milk fat: a new challenge for the quality of food products
}

\author{
Christelle LOPEZ*, Valérie BRIARD-BION \\ UMR1253 Science et Technologie du Lait et de l'Euf, INRA-Agrocampus Rennes, \\ 65 rue de Saint-Brieuc, 35042 Rennes Cedex, France
}

\begin{abstract}
In this paper, we focused on the characteristics of milk fat (composition, organisation and thermal properties) that may improve the functional, sensory and nutritional properties of food products. Fat is dispersed in raw milk as droplets called milk fat globules, which are enveloped in their biological membrane (MFGM). Dairy processes may greatly affect both the supramolecular organisation and the surface composition of fat. Using confocal laser scanning microscopy, we showed that fat can be dispersed as natural milk fat globules $\left(\mathrm{d}_{\text {mean }} \sim 4 \mu \mathrm{m}\right)$, coalesced fat globules $(10-20 \mu \mathrm{m})$, aggregates of fat globules $(10-50 \mu \mathrm{m})$, tiny homogenised fat globules $(0.2-1 \mu \mathrm{m})$ covered mainly by caseins, and at the extreme opposite, non-globular fat, also called free fat. Fat can also be the continuous phase such as in butter and in its anhydrous form. We focused on the changes in the organisation of fat during the manufacture and ripening of a hard-type cheese and showed that the pressing of curd grains leads to the disruption of the MFGM and the formation of free fat. Furthermore, the pockets of whey surrounding the inclusions of fat after disruption of the MFGM favour the preferential localisation of bacteria at the fat/protein interface and thus contribute to the accessibility of lipolytic enzymes to fat for lipolysis, essential for the quality of cheese. An innovative method was developed using differential scanning calorimetry to determine the solid fat content in food products. We showed that the fat phase is partially crystallised in cheese for $\mathrm{T}<41{ }^{\circ} \mathrm{C}$, e.g. a mixture of crystals and oil, and calculated that about $56 \%$ of fat was solid at $4{ }^{\circ} \mathrm{C}$. Finally, we showed that increasing the amount of unsaturated fatty acids in milk fat to improve its nutritional properties changes the solid fat content as a function of temperature, the resistance of fat globules to disruption and thus the functional, textural and sensorial properties of fat-rich products such as butter.
\end{abstract}

structure of fat / solid fat content / fat globule / lipolysis / confocal laser scanning microscopy

摘要 - 组成、超分子组织和乳脂肪的热特性: 食品质量的一个新的挑战。本文针对能够 改变食品功能, 感官及营养特性的乳脂肪的性质 (组成、组织、热特性) 进行了研究。脂肪 是以天然脂肪球的形式分散在原料乳中, 乳脂肪球被一层生物膜所包裹 (MFGM)。乳品加工 过程对超大分子组织和脂肪表面的组成都能够产生显著的影响。采用激光扫描共聚焦显微

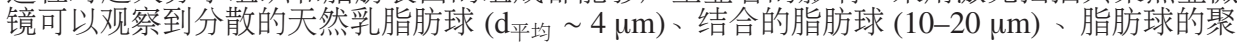
集体 $(10-50 \mu \mathrm{m})$ 、均质过的由酪蛋白包裹的微小脂肪球 $(0.2-1 \mu \mathrm{m})$ 、以及无脂肪球存在 的极端情况 (即所谓的游离脂肪)。脂肪可以形成连续相, 如在奶油中或在无水状态下的脂 肪。我们针对性地研究了埃门塔尔 (Emmental) 干酪制造和成熟过程中脂肪组织的变化, 研

* Corresponding author (通讯作者): Christelle.Lopez@ rennes.inra.fr 


\begin{abstract}
究结果表明凝乳颗粒的压榨会导致脂肪球膜的破裂 (MFGM) 形成游离脂肪。此外, 脂肪球 膜破裂后乳清蛋白将游离脂肪包裹起来,这种情况会使得细菌优先定殖在脂肪和蛋白的交界 处, 极易发生脂肪酶对脂肪的脂解作用, 进而影响了干酪的质量。一种改进的差示量热扫描 方法用于测定食品中固体脂肪含量, 实验证明干酪中脂肪相是部分结晶的, 当 $\mathrm{T}<41^{\circ} \mathrm{C}$ 时脂 肪是脂肪晶体和油脂的混合物, 而在 $4{ }^{\circ} \mathrm{C}$ 脂肪中, 固体脂肪含量为 $55.7 \pm 3.5 \%$ 。最后, 我们 证明了增加乳脂肪中不饱和脂肪酸的含量可以改善它的营养特性, 改变脂肪中固体脂肪含量 与温度的函数关系, 可以抵抗脂肪球的破裂, 以及对富含乳脂肪的产品, 如奶油的功能、质地 和感官特性都有一定的改善作用。
\end{abstract}

\title{
脂肪结构 / 固体脂肪含量 / 脂解 / 激光扫描共聚焦显微镜 / 差示量热扫描仪
}

\begin{abstract}
Résumé - Composition, organisation supramoléculaire et propriétés thermiques de la matière grasse laitière : un nouveau challenge pour la qualité des produits alimentaires. Dans cet article, nous nous focalisons sur les caractéristiques de la matière grasse du lait (composition, organisation, propriétés thermiques) qui peuvent améliorer les propriétés fonctionnelles, sensorielles et nutritionnelles des aliments. La matière grasse est dispersée dans le lait cru sous forme de gouttelettes, appelées globules gras, enveloppées par leur membrane biologique naturelle. Cependant, les procédés industriels peuvent modifier l'organisation de la matière grasse et la composition de sa surface. En utilisant la microscopie confocale, nous avons montré que la matière grasse peut être dispersée sous forme de globules gras natifs $\left(\mathrm{d}_{\text {moyen }} \sim 4 \mu \mathrm{m}\right)$, de globules gras coalescés $(10-20 \mu \mathrm{m})$, d'agrégats de globules gras $(10-50 \mu \mathrm{m})$, de petites gouttelettes homogénéisées $(0,2-1 \mu \mathrm{m})$ majoritairement recouvertes de caséines, et sous forme non globulaire aussi appelée matière grasse libre. La matière grasse peut également constituer la phase continue comme dans le beurre. Nous avons étudié les évolutions d'organisation de la matière grasse au cours de la fabrication et de l'affinage de l'Emmental et montré que le pressage des grains de caillé conduit à la rupture de la membrane des globules gras et à la formation de matière grasse libre. De plus, les poches de sérum entourant les inclusions de matière grasse favorisent la localisation préférentielle des bactéries à l'interface avec le réseau protéique. Ce travail a contribué à l'élucidation des mécanismes d'accessibilité des enzymes lipolytiques, dont l'action est essentielle à la qualité du produit. Par ailleurs, une méthode innovante a été développée pour déterminer la quantité de matière grasse cristallisée dans les produits, en utilisant la microcalorimétrie différentielle. Nous avons montré que la phase grasse est partiellement cristallisée dans les matrices fromagères (mélange d'huile et de cristaux) pour $\mathrm{T}<41^{\circ} \mathrm{C}$, et que environ $56 \%$ de la matière grasse est solide à $4{ }^{\circ} \mathrm{C}$. Enfin, nous avons montré qu'une augmentation de la quantité des acides gras insaturés, visant à améliorer les qualités nutritionnelles de la matière grasse laitière, modifie le taux de solide, la résistance des globules à la rupture sous contrainte et en conséquence les propriétés fonctionnelles et sensorielles des produits riches en matière grasse, particulièrement le beurre.
\end{abstract}

\section{structure / taux de solide / lipolyse / globule gras / microscopie confocale}

\section{INTRODUCTION}

Milk fat is widely consumed in dairy products, i.e. milk, cream, ice cream, whipped cream such as Chantilly, cheeses and butter, but also in powders, pastries, cooked foods, etc. Considering its implication in the texture, the mouth-feel, the flavour and the functional properties, milk fat plays a major role in the quality of highfat products. However, the negative health aspects of milk fat, which are mainly due to its high concentration in saturated fatty acids and cholesterol, limit its consumption. Thus, modification of milk fat composition and physical properties to improve its nutritional but also its functional properties is of considerable interest for expanding its consumption and its use in the cosmetic, pharmaceutical and food industries.

The concentration and chemical composition of fat in food products are easily determined and thus well known. On the other hand, information on the properties of fat in situ in food products are scarce. Thus, increasing the knowledge of 
the suprastructure of milk fat and thermal properties (i.e. solid fat content at a fixed temperature) in food products as a function of its fatty acid composition is of tremendous importance with respect to technological, functional, sensorial and nutritional properties.

Regarding more particularly the structure of fat in food products, some elements are assumed. In milk, cream and yoghurt, fat is consumed as a direct emulsion with the fat globules being dispersed in the plasma phase: natural fat globules $(\mathrm{d} \sim 4 \mu \mathrm{m})$ are covered by their biological membrane (the milk fat globule membrane: MFGM), while tiny homogenised fat globules are mainly covered by caseins [8]. In ice cream and whipped cream, partially coalesced fat globules, fat crystals and polar lipids are adsorbed on the surface of air bubbles. In butter, fat is consumed as a reverse emulsion in which water droplets are dispersed in the continuous partially crystallised fat phase.

The organisation of fat in other processed food products is unclear. For example, in cheeses, fat is entrapped in a protein network, but its suprastructure depends greatly on the technological process applied. During the processing of milk, several treatments may alter the natural structure of fat globules and damage the MFGM: (i) mechanical treatments, i.e. pumping, agitation, cutting, pressing and high-pressure homogenisation; (ii) thermal treatments, i.e. refrigeration, heating (pasteurisation, sterilisation), drying; and (iii) enzymatic treatments, i.e. lipolysis. In spite of the great significance of the physical structure of milk fat and the interactions between fat and proteins, regarding lipase activity and the functional properties, only a few authors have studied the organisation of fat in complex food products.

Microstructure studies provide a key to understanding, and therefore controlling, the properties of food products. Consider- ing the characterisation of the supramolecular structure of fat in situ in a complex matrix, the development of adequate protocols and the choice of non-destructive methods is essential. Confocal laser scanning microscopy (CLSM) is a powerful tool to penetrate the surface of a sample and to visualise thin optical sections. The use of CLSM provides an opportunity to characterise milk fat globules in food products, without disturbing the internal structure, and to localise simultaneously the main elements of structure: fat, proteins, bacteria, exopolysaccharides, etc. $[1,3,4,8,12,15,21]$.

Regarding the thermal properties of milk fat, studies have mainly been performed with anhydrous milk fat and cream, but few studies have been performed in complex food products [12]. The complex composition of milk fat and polymorphism of triacylglycerols (TG) are responsible for its thermal behaviour: milk fat has a broad melting range, which spans from about -40 to $40{ }^{\circ} \mathrm{C}$ [22]. This means that at intermediate temperatures and at the temperatures of storage $\left(4-7{ }^{\circ} \mathrm{C}\right)$ and consumption, milk fat is partially crystallised and corresponds to a mixture of solid fat, e.g. crystals, and liquid fat, e.g. oil. The characteristic melting profile of anhydrous milk fat recorded using differential scanning calorimetry (DSC) shows 3 peaks corresponding to groups of TG that melt separately: the low melting point (LMP), middle melting point (MMP) and high melting point (HMP) fractions [22]. Using polarised light microscopy, it was evidenced that the kinetics of cooling and tempering affect the size of TG crystals and their localisation in fat globules [10,11]. Recently, Ollivon and colleagues characterised at a molecular level the crystallisation properties of milk fat in bulk, i.e. anhydrous milk fat $[7,11,13]$ and in natural milk fat globules $[9,10,19]$, using coupling of timeresolved synchrotron X-ray diffraction and 
DSC. The longitudinal organisation of TG molecules and the lateral packing of fatty acids in the subcells (sub- $\alpha, \alpha, \beta^{\prime}, \beta$ ) were characterised $[10,11]$. Understanding the textural and functional behaviour of fat in complex products cannot be achieved without the full characterisation of the thermal properties: types of crystals formed and solid fat content at a fixed temperature.

The composition of milk fat, its organisation and its thermal properties in food products have major consequences on their functional, textural, sensorial and nutritional properties. Moreover, the structure and texture of dairy gels are affected by the interactions between the surface of fat droplets and the casein network. Fat droplets can be inert fillers (fat globules with the natural MFGM), structure breakers (large fat globules), or can act as structure promoters (fat droplets covered by caseins), depending on their size and the properties of their surface [17]. The role of milk fat globules in the functionality of different kinds of cheeses, such as Mozzarella cheese and Emmental cheese, has recently been explored [20,21]. The effect of technological and compositional parameters as well as the size of the fat globules in Mozzarella cheese have been shown to be related to meltability and free fat formation [21]. From a sensorial point of view, the majority of flavour compounds are at least partially soluble in liquid fat, suggesting that the fat acts as a reservoir of flavour compounds. Additionally, fat may facilitate flavour generation by providing a fatprotein interface for flavour-producing reactions to occur.

The objectives of this study were (i) to characterise the organisation of fat in commercial dairy products, (ii) to characterise the changes in the organisation of fat during the manufacture of a hard-type cheese and their consequences on the accessibility of fat to lipolytic enzymes, (iii) to determine the solid fat content in cheese, and (iv) to determine the consequences of increasing the amount of unsaturated fatty acids on the properties of food products.

\section{MATERIALS AND METHODS}

Commercial dairy products (cheeses, butter and milk powder) were used in this work. Emmental cheeses were manufactured using a specialised pilot plant based in the research centre of INRA, Rennes, France, as described in Lopez et al. [15].

\subsection{Particle size measurements}

The fat globule size distributions in milks were measured by laser light scattering using a Mastersizer 2000 (Malvern Instruments, Malvern, UK), equipped with a He/Ne laser $(\lambda=633 \mathrm{~nm})$ and an electroluminescent diode $(\lambda=466 \mathrm{~nm})$. The refractive index of milk fat was taken to be 1.460 at $466 \mathrm{~nm}$ and 1.458 at $633 \mathrm{~nm}$ as previously determined in our laboratory.

\subsection{Microstructural analysis}

Dairy product microstructure was examined using confocal laser scanning microscopy (CLSM). Thin slices of cheese and butter $(5 \mathrm{~mm} \times 5 \mathrm{~mm} \times 3 \mathrm{~mm}$ thick) were prepared from the freshly cut samples. Milk powder was dispersed in glycerol to avoid its solubilisation. A lipidsoluble Nile Red fluorescent dye (Sigma Aldrich, St Louis, USA) was used to label fat. The protein network and DNA of bacteria were stained using Acridine Orange fluorescent dye (Aldrich Chemical Company, Inc., Milwaukee, USA). Microstructural analysis was performed using a confocal Leica TCS NT microscope (Leica Microsystems, Heidelberg, Germany), with excitation wavelengths of $568 \mathrm{~nm}$ for fat and $488 \mathrm{~nm}$ for protein and bacteria. 


\subsection{Thermal properties}

The thermal properties of the samples were monitored by differential scanning calorimetry (DSC) using a TA Q-1000 calorimeter (TA-Instruments, New Castle, USA).

\subsubsection{Cheeses and butters}

About 40 to $50 \mathrm{mg}$ were accurately weighted in a hermetic stainless steel pan of $100 \mu \mathrm{L}$. An empty hermetic stainless steel pan was used as reference. The samples stored at $4{ }^{\circ} \mathrm{C}$ were transported in an isothermal box to the calorimeter, precooled to $4{ }^{\circ} \mathrm{C}$. The samples were tempered for $5 \mathrm{~min}$ at $4{ }^{\circ} \mathrm{C}$ and heated from $4{ }^{\circ} \mathrm{C}$ to $60{ }^{\circ} \mathrm{C}$ at $2{ }^{\circ} \mathrm{C} \cdot \mathrm{min}^{-1}$.

\subsubsection{Anhydrous milk fat}

About 5 to $10 \mathrm{mg}$ of AMF extracted from the samples were weighed in a hermetic aluminium pan of $50 \mu \mathrm{L}$. The samples were heated to $60{ }^{\circ} \mathrm{C}$ to melt all nuclei, cooled from $60{ }^{\circ} \mathrm{C}$ to $-40{ }^{\circ} \mathrm{C}$ at $-2{ }^{\circ} \mathrm{C} \cdot \mathrm{min}^{-1}$ and heated from $-40{ }^{\circ} \mathrm{C}$ to $60{ }^{\circ} \mathrm{C}$ at $2{ }^{\circ} \mathrm{C} \cdot \mathrm{min}^{-1}$. The thermal characteristics (initial $\mathrm{T}$ of crystallisation, final $\mathrm{T}$ of melting and enthalpy of melting) were calculated by the instrument software.

\section{RESULTS AND DISCUSSION}

\subsection{Natural milk fat globules: structure and composition}

Fat is present in milk in the form of spherical droplets called milk fat globules (MFG; Fig. 1). MFG have a diameter ranging from 0.02 to $15 \mu \mathrm{m}$ with a volume-weighted diameter of about $4 \mu \mathrm{m}$ (Fig. 1) [8].

Milk fat is mainly composed of neutral lipids, the triacylglycerols (TG; 98\% of total lipids) which are triesters of glycerol and fatty acids (Fig. 1, top). With the particularity of having short-chain (C4-C8: 8.3\%), medium-chain (C10-C12: 6.6\%) and long-chain (C14-C18: 81.9\%) fatty acids [5], milk fat is one of the most complex natural fats. Moreover, milk fat is a relatively high saturated fat: about 65 to $70 \%$ of saturated fatty acids (mainly C16:0, C18:0 and C14:0) and about 30 to $35 \%$ of unsaturated fatty acids (mainly C18:1). These wide ranges of fatty acid chain length and degree of unsaturation are responsible for the complex composition of milk fat; more than 400 different fatty acids and 200 TG have been identified $[2,5]$.

Natural milk fat globules are enveloped by a biological membrane, the milk fat globule membrane (MFGM), which consists of proteins, glycoproteins, enzymes, phospholipids, cholesterol and other minor components [16] (Fig. 1). Both the structure in a trilayer (thickness $\sim 4-10 \mathrm{~nm}$ ) and composition of the native MFGM result from the mechanisms of secretion of fat globules by the epithelial cells of the mammary gland [6]. The MFGM acts as a natural emulsifying agent that prevents aggregation and coalescence of milk fat, and is also a barrier that protects the fat against lipolytic enzymes. Thus, the natural MFGM confers specific properties upon fat globules.

\subsection{Processes affect the organisation of fat in dairy products}

Milk fat is present in food products with a concentration varying from about $15 \mathrm{~g} \cdot \mathrm{kg}^{-1}$ (semi-skimmed milk) to about $820 \mathrm{~g} \cdot \mathrm{kg}^{-1}$ in butter. The chemical characteristics, e.g. dry matter, fat content and composition, but also the organisation of fat (emulsified or non-emulsified) may affect the properties of products. For the last 


\section{Raw milk: natural milk fat globules}

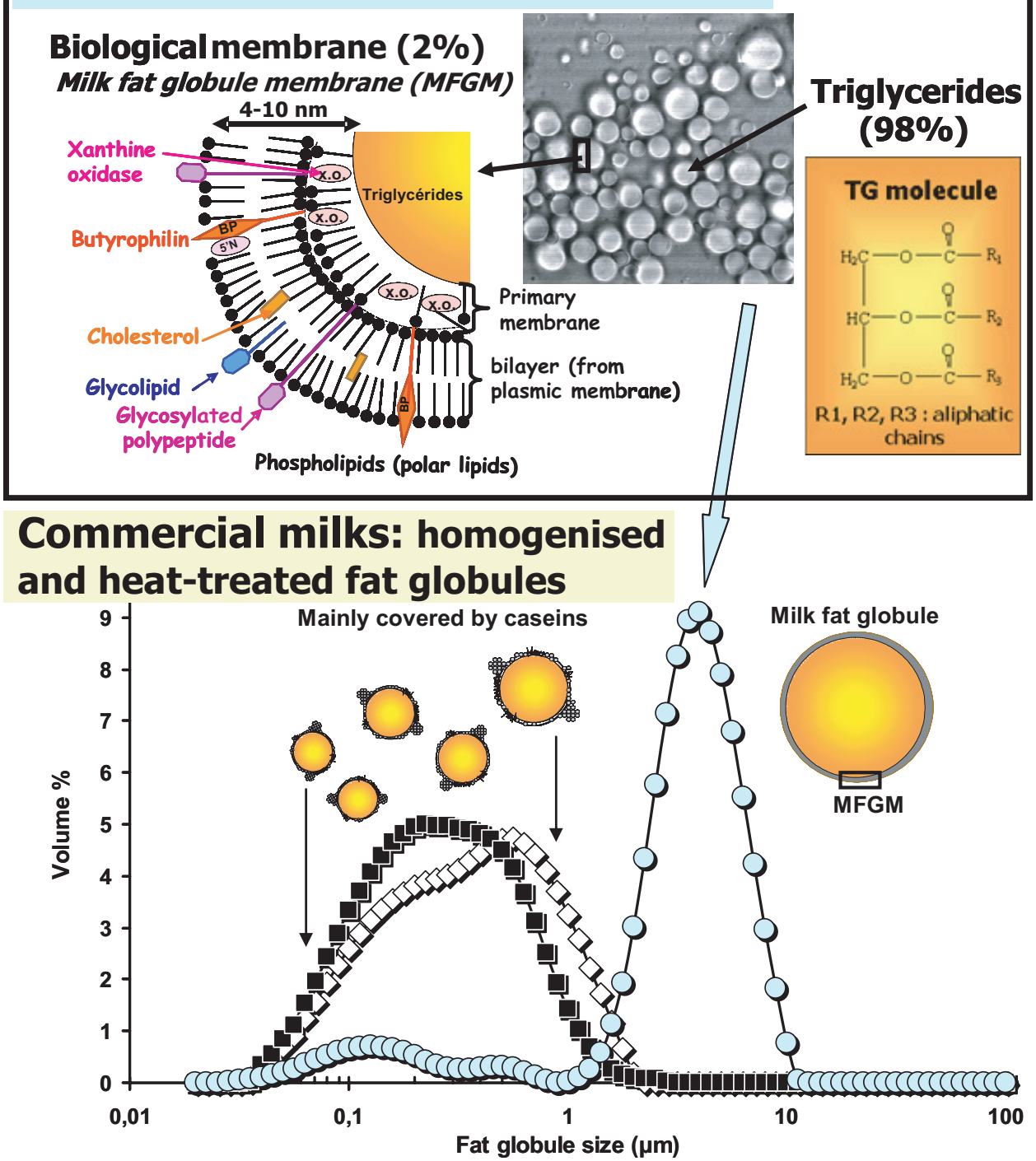

Figure 1. Natural milk fat globules and fat droplets after homogenisation: composition and structure. Top: Light micrograph of milk fat globules and schematic representation of the milk fat globule membrane and the core of fat globules composed of triglycerides. Bottom: Milk fat globule size distribution in full-fat raw milk (-o-), full-fat pasteurised milk (- $\left.\diamond_{-}\right)$and full-fat UHT milk (- - -$)$, measured by laser light scattering and schematic representation of fat droplets covered mainly by caseins. 
3 years, we have focused on the structure of fat in various food products to improve the understanding of its functional properties.

Figure 1 shows comparatively the size distributions of milk fat globules in raw and commercial milks. The volumeweighted average diameter of fat globules in drinking milks is in the range 0.2-0.5 $\mu \mathrm{m}$ [8]. Milk directly from the cow is rarely consumed due to fears regarding possible microbiological risks and also the perception of increased fat intake, due to the fat layer that develops on the milk surface when left to stand. Thus, commercial milk undergoes technological treatments: heat treatment and homogenisation, to prevent its microbiological and physical unstability, respectively. Homogenisation is of special interest in the dairy industry to reduce the size of fat globules in milk and creams, and to prevent creaming and coalescence during long shelf-storage. Homogenisation of milk is also performed to favour lipolysis, e.g. in blue-veined cheeses. Homogenisation of fat globules leads to the total or at least partial disruption of the MFGM and to the adsorption of milk proteins (mainly caseins) and greatly increases the interfacial surface area of fat in solution by increasing the number of fat globules. The fraction $\Phi$ of the milk fat globule surface that is covered by milk proteins after processing of commercial milks was quantified; it corresponds to $66-87 \%$ [8].

Figure 2 shows the microstructure of different kinds of products observed using CLSM. In all the micrographs, the fat is coloured in red, the proteins appear in grey level and the bacteria in green. Figures $2 \mathrm{~A}$ and $2 \mathrm{~B}$ show the microstructure of two different soft cheeses. In Camembert cheese, manufactured with the traditional technology, fat remains essentially in its globular form, covered by the MFGM (Fig. 2A). The size of some fat globules is larger than that found in milk, which shows that the heat and mechanical treatments applied during the process induced some coalescence of fat globules. Figure 2B shows the microstructure of a low-fat soft cheese made with ultrafiltration technology. Fat is dispersed as small fat globules, $\sim 1-2 \mu \mathrm{m}$, meaning that homogenisation or high shear was used during the process. Thus, the MFGM was disrupted and caseins may mainly cover the surface of the fat globules. This decrease in size of fat globules and change in interfacial properties (MFGM vs. caseins) lead to different fat - casein interactions during the formation of the network. It is well known that homogenised fat globules highly interact with the casein network during renneting of milk and highly contribute to the rheological properties of the cheese (higher elastic modulus). Figure 2C shows the microstructure of processed cheese, manufactured mainly with hard-type cheese, butter and polyphosphates. The mixing of the ingredients under shear and at high temperature leads to the emulsification of fat and the formation of small droplets $(0.2-1 \mu \mathrm{m})$ covered by casein strands. Figure $2 \mathrm{D}$ shows the microstructure of a hardtype cheese, Cheddar cheese, in which fat is mainly dispersed as aggregates of fat globules and free fat, which is the fat not covered by the MFGM. A small proportion of fat globules also remains in the casein matrix. Figure 2E shows the microstructure of a traditional butter (churning process). It corresponds to small droplets of water and residual fat globules dispersed in a continuous phase of partially crystallised fat. Thus, traditional butter can be considered as a mixed emulsion (dispersed phase: water droplets + residual fat globules + bacteria). Figure $2 \mathrm{~F}$ shows the organisation of fat in a spray-dried dairy powder: globular fat and surface free fat were observed.

We showed that the supramolecular structure of milk fat in food products can be drastically different, depending on the technological process applied during the 

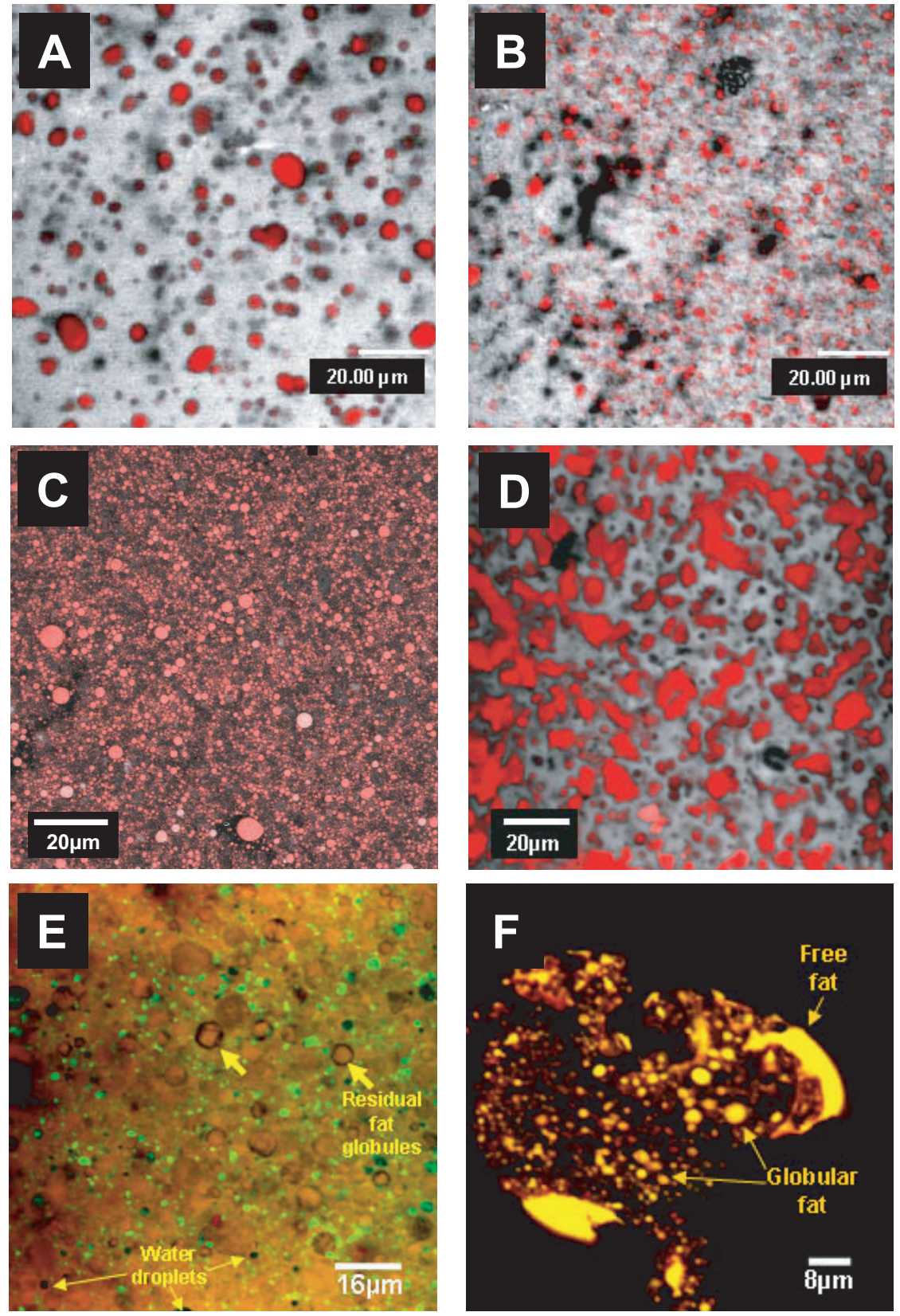

Figure 2. Confocal laser scanning micrographs of commercial dairy products. Soft cheeses: (A) traditional Camembert cheese and (B) soft cheese made with ultrafiltration technology; (C) processed cheese; (D) hard-type cheese: Cheddar; (E) traditional butter made with churning process; (F) spray-dried dairy powder. Fat is coloured in red/orange, proteins are in grey level, bacteria are in green. 
manufacture. Cheeses are dispersions of fat in a casein network. Thus, they correspond to dense oil in water emulsions in which milk fat can be dispersed as (i) fat globules with the MFGM $(\sim 4 \mu \mathrm{m})$, (ii) aggregates of fat globules $(10-50 \mu \mathrm{m})$, (ii) homogenised fat globules covered by caseins $(0.2-1 \mu \mathrm{m})$, (iii) free fat, and (iv) a combination of different phases and structures (Fig. 3) [8]. Butter is traditionally considered as a water-in-oil emulsion. However, we showed that it is also a dispersion of residual fat globules in a continuous fat phase.

\subsection{Changes in the organisation and the thermal properties of fat during the manufacture and ripening of Emmental cheese}

Emmental cheese is probably the bestknown Swiss-type cheese, and is the most widely manufactured hard cheese in France. Changes in the physico-chemical properties, organisation and thermal properties of milk fat were investigated during the main steps involved during the manufacture and ripening of Emmental (Fig. 4) [15].

\subsubsection{The manufacture of cheese greatly affects the properties offat}

The measurement of fat globule size and apparent zeta potential (to estimate MFGM damage) showed that they were slightly affected during cheese milk preparation, i.e. storage of cheese milk overnight at $4{ }^{\circ} \mathrm{C}$ and thermisation. CLSM was used to investigate the organisation of fat after coagulation of milk (Fig. 5). The rennet-induced casein network had a porous structure in which milk fat globules were entrapped (Fig. 5A). After cutting and heating of curd grains, fat globules existed in two states, as individual globules entrapped in the protein network and as aggregates. Pressing of curd grains and acidification induced the largest changes in the structure and composition of the curd: a large increase in the density of the protein network and milk fat globule disruption were observed (Fig. 5B). Emmental cheese microstructure after pressing of curd grains consisted of cavities containing fat globules and serum phase, surrounded by protein strands. Fat was present in different forms: (i) milk fat globules which have the same size as that detected following milk coagulation ( $\mathrm{d} \sim 4-5 \mu \mathrm{m})$, (ii) aggregates of fat globules, (iii) coalesced fat globules formed after fusion of several fat globules of smaller size, and (iv) nonglobular fat, also called free fat. Free fat is the fat which is not protected by the MFGM, and susceptible to oiling off or removal (Fig. 3). The disruption of milk fat globules during pressing of curd grains can depend on several parameters such as (i) their size, (ii) their aggregation through the partly reorganised MFGM, (iii) the composition of fat which governs its solid fat content, (iv) the composition, structure and properties of the MFGM, (v) the viscosity of the casein network, and (vi) the parameters of pressing: temperature, time and pressure applied. Pressing, identified as the main destabilising process, resulted in the greatest disruption of fat globules and plays a major role in the formation of free fat. Following the disruption of the MFGM, membrane material is released and the surface-active components that remain in the cheese matrix may have an impact on the functional, sensory and nutritional properties. Figure 5C shows the microstructure of Emmental cheese after brining.

The thermal properties of fat dispersed in Emmental cheese were investigated in situ using DSC. The samples were first heated to $60{ }^{\circ} \mathrm{C}$, e.g. above the final melting point of milk fat, in order to 

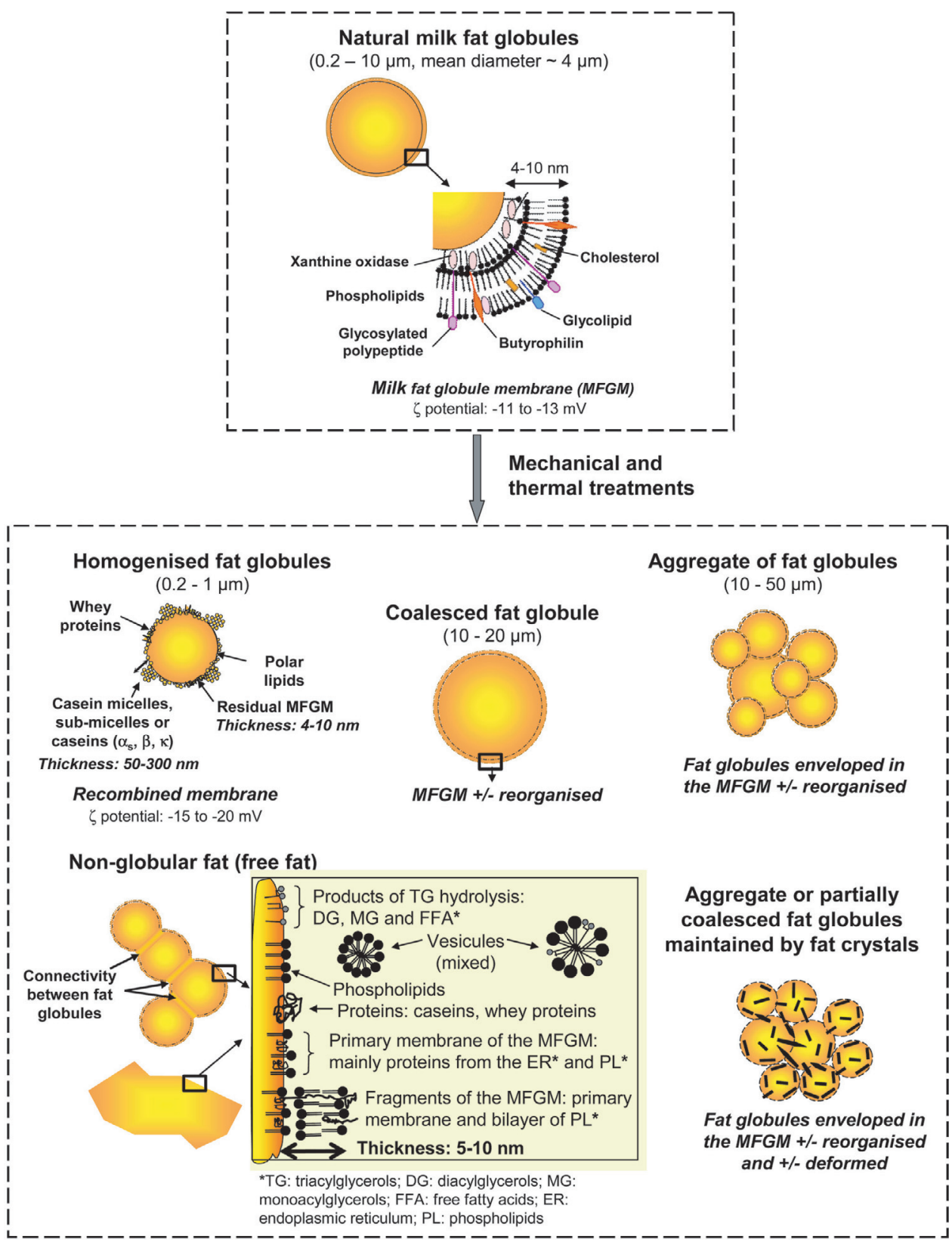

Figure 3. Schematic representation of the supramolecular organisation of milk fat in food products and proposed composition and structure of the fat/water interface (not to scale). 


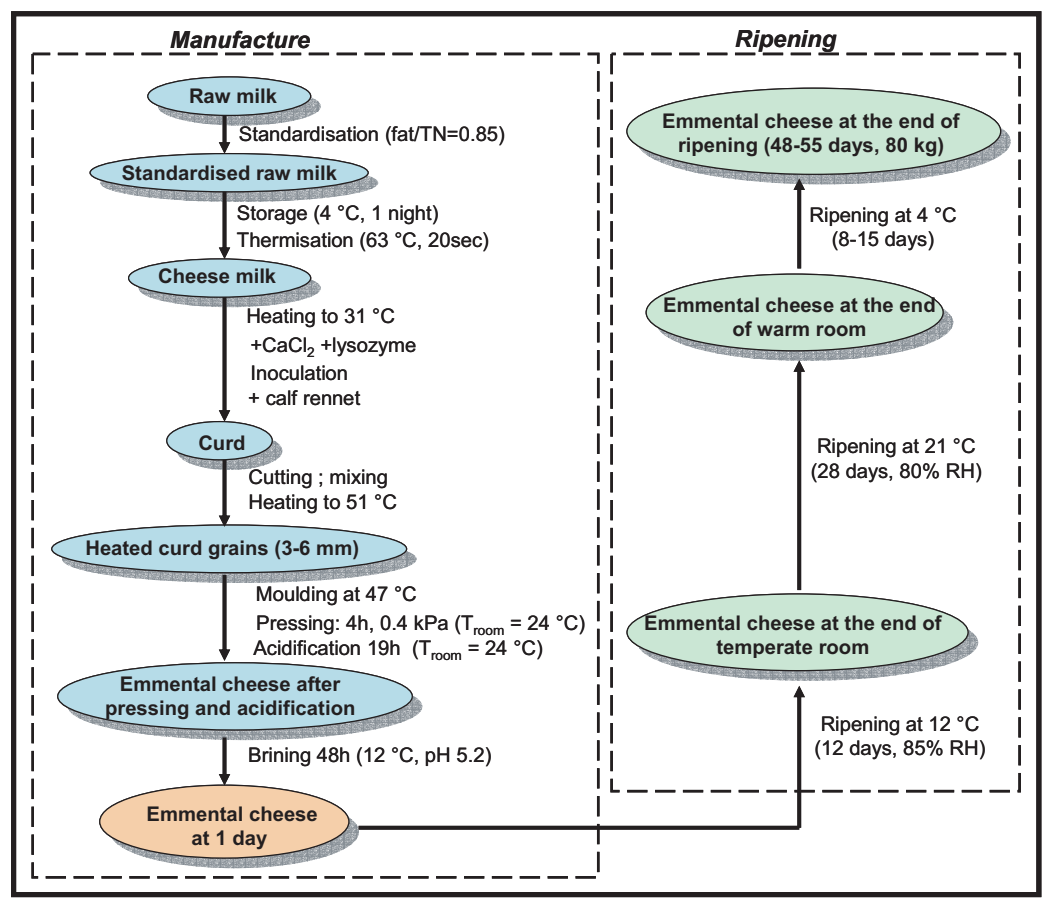

Figure 4. Schematic representation of the main steps involved during the manufacture and ripening of Emmental cheese.

melt all existing nuclei and thus eliminate their thermal history. The liquid $\rightarrow$ solid fat transition was observed upon cooling. Cheese samples were not cooled at $\mathrm{T}<$ $-6{ }^{\circ} \mathrm{C}$ to avoid ice formation. We showed that the destabilisation of fat globules by coalescence and the formation of free fat after pressing alter the thermal properties of milk fat (i) by increasing the initial temperature of crystallisation, and (ii) by the formation of two overlapped exotherms (details in [12]).

\subsubsection{Ripening of cheese regarding the properties of fat}

\subsubsection{Organisation of fat in the cheese matrix}

At a microscopic level, the gross structural view of Emmental cheese during ripening is different from that observed after brining; the pockets of serum which had surrounded the pools of fat have disappeared, increasing the contact between fat and the casein network (Fig. 6). During ripening, the microstructure of Emmental cheese does not evolve significantly. However, at a molecular level fat globules can (i) become disrupted due to enzymatic hydrolysis of the MFGM, and (ii) be distorted by protein rearrangements due to proteolysis during cheese ripening which may contribute to the formation of the pools of fat. The temperature of ripening can also contribute to the destabilisation of fat globules in the casein matrix during the ripening period by increasing the amount of fat in the solid state, which can damage the MFGM.

This study showed that milk fat exists in three main forms in Emmental cheese: (i) small fat globules enveloped by the 

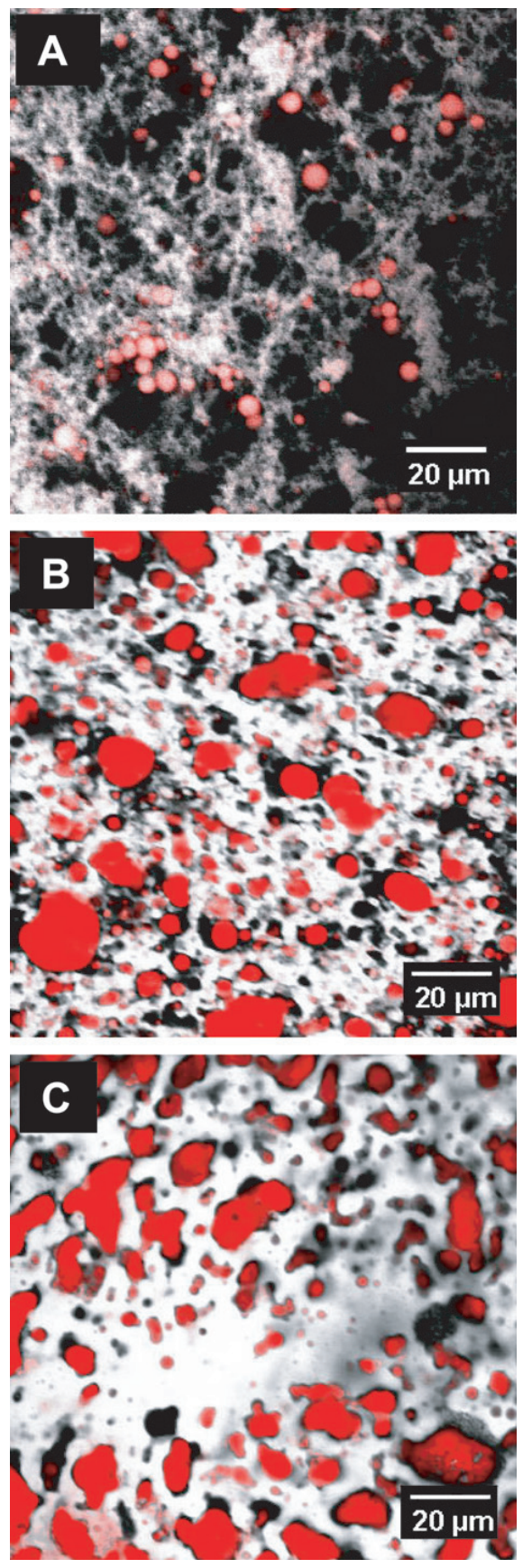

Figure 5. Confocal laser scanning micrographs taken during the manufacture of Emmental cheese: (A) milk curd; (B) Emmental cheese after pressing $\left(0.4 \mathrm{kPa}, 4 \mathrm{~h}, 47^{\circ} \mathrm{C}\right)$; (C) Emmental cheese after brining. Fat is coded in red, proteins are in grey level, pockets of whey are in black. 

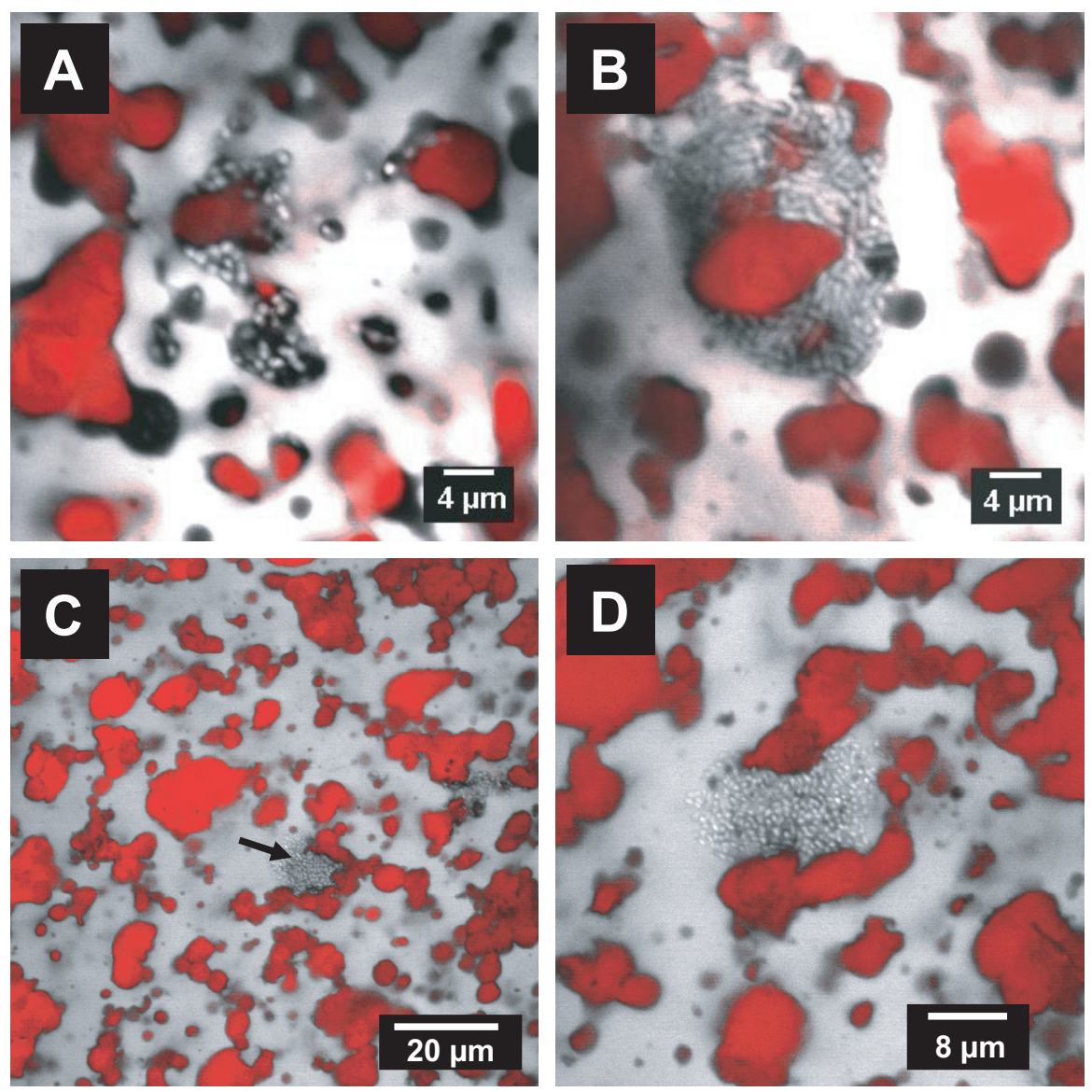

Figure 6. Confocal laser scanning micrographs taken in Emmental cheese at 1 day (A and $\mathbf{B})$ and at the end of ripening ( $52 \mathrm{~d} ; \mathbf{C}$ and $\mathbf{D}$ ). These figures show the preferential localisation of bacteria in the pockets of whey surrounding fat inclusions $(\mathbf{A})$ and at the fat/protein interface $(\mathbf{B}, \mathbf{C}$ and $\mathbf{D})$. The protein network and bacteria (bright areas) are coded in white, fat is coded in red. Whey pockets appear in black.

MFGM, (ii) aggregates of partially disrupted fat globules, and (iii) free fat, resulting from the disruption of the MFGM and allowing free TG to fill voids in the cheese protein matrix [15]. However, the organisation of the fat probably exists as a continuum between these three states, depending on the degree of breakdown of the MFGM. A schematic representation of the composition and structure of the fat/whey interface after disruption of the MFGM is proposed in Figure 3.

\subsubsection{Lipolysis, considering the organisation of fat and preferential localisation of bacteria}

Figures $6 \mathrm{~A}$ and $6 \mathrm{~B}$ show colonies of bacteria localised in the pocket of whey 
surrounding fat inclusion (Fig. 6A) and at the fat/protein interface (Fig. 6B) in Emmental cheese at 1 day. Figure 6C shows the microstructure of Emmental cheese at the end of ripening with an enlarged scale of Figure 6D to observe a colony of bacteria better. The preferential localisation of the bacteria at the fat/protein interface and the disruption of the MFGM after pressing of curd grains (Fig. 5B) can favour the accessibility of fat to lipolytic enzymes. The level of lipolysis at the end of ripening corresponded to $1.56 \%$ of fat, which is the amount expected for Emmental cheese [14]. The amount of free fatty acids (FFA) progressively released during the manufacture and ripening, expressed in $\%$ of total FFA, was $14.3 \pm 0.8 \%$ after brining, $0.9 \pm 0.1 \%$ after $12 \mathrm{~d}$ at $12{ }^{\circ} \mathrm{C}$, $68.2 \pm 7.6 \%$ after $28 \mathrm{~d}$ at $21^{\circ} \mathrm{C}$ and $16.6 \pm$ $1.7 \%$ after $8 \mathrm{~d}$ at $4{ }^{\circ} \mathrm{C}$ [14]. The nonselectivity of lipolytic enzymes was evidenced: all fatty acids were released with a level $\geqslant 1 \%$.

DSC experiments showed that the initial temperature of crystallisation was delayed and the final temperature of melting was lowered as a function of the increase in FFA due to lipolysis (Fig. 7). Thus, the thermal properties of cheese were affected by (i) lipolysis of fat, that is, the monoacylglycerols, diacylglycerols and FFA that may be localised at the fat/whey interface (Fig. 3), and/or by (ii) hydrolysis of highmelting point TG constituting mainly longchain saturated fatty acids (e.g. palmitic acid).

\subsubsection{Fat is partially crystallised in cheese}

The melting properties of fat dispersed in Emmental cheese were characterised in the different temperature-controlled rooms used during ripening: $\mathrm{T}_{\text {ripening }}=12{ }^{\circ} \mathrm{C}$, $21{ }^{\circ} \mathrm{C}$ and $4{ }^{\circ} \mathrm{C}$. The DSC melting curve recorded at the end of ripening showed the 3 endothermic peaks corresponding to LMP, MMP and HMP fractions (Fig. 8A), as described for anhydrous milk fat [22]. We showed that the final melting point of fat in Emmental cheese stored at $4{ }^{\circ} \mathrm{C}$ at the end of ripening was $40.76 \pm 0.25^{\circ} \mathrm{C}$, which means that the fat was totally liquid at this temperature. Thus, fat in Emmental cheese is partially crystallised between $4{ }^{\circ} \mathrm{C}$ and about $41^{\circ} \mathrm{C}$. We developed an innovative method using the DSC technique to determine the ratio of solid to liquid fat, e.g. the amount of fat which is crystallised in cheese as a function of temperature, by dividing the partial enthalpy of melting of the fat for $\mathrm{T}_{\text {ripening }}$ by the total enthalpy of melting of the same fat extracted from cheese. We showed that during ripening of Emmental cheese, $44.1 \pm 5.7 \%$ of the fat were crystallised after $16 \mathrm{~d}$ in the $12{ }^{\circ} \mathrm{C}$ room, $18.8 \pm 2.0 \%$ of fat were crystallised after $28 \mathrm{~d}$ in the $21{ }^{\circ} \mathrm{C}$ room and $55.7 \pm 3.5 \%$ of the fat were crystallised in an Emmental cheese stored at $4{ }^{\circ} \mathrm{C}$ at the end of ripening [12]. The solid fat content within Emmental cheese stored at $4{ }^{\circ} \mathrm{C}$ after its ripening process was calculated as a function of temperature by constructing an integral curve from the DSC melting thermogram (Fig. 8B). The amount of fat which was solid for $\mathrm{T}>37{ }^{\circ} \mathrm{C}$ was calculated to be $3 \%$ (w/w) (Fig. 8B).

The existence of fat crystals may have important consequences on the textural and rheological properties of cheese. Furthermore, the amount, size and type of crystals may have primordial importance for final product consistency, acceptability and functional properties. Indeed, some aroma compounds are solubilised in the liquid phase of fat and their release may depend on the ratio of solid to liquid fat. Furthermore, the melting of fat crystals may contribute to the release of these aroma compounds and to the mouth-feel during consumption of Emmental cheese. 


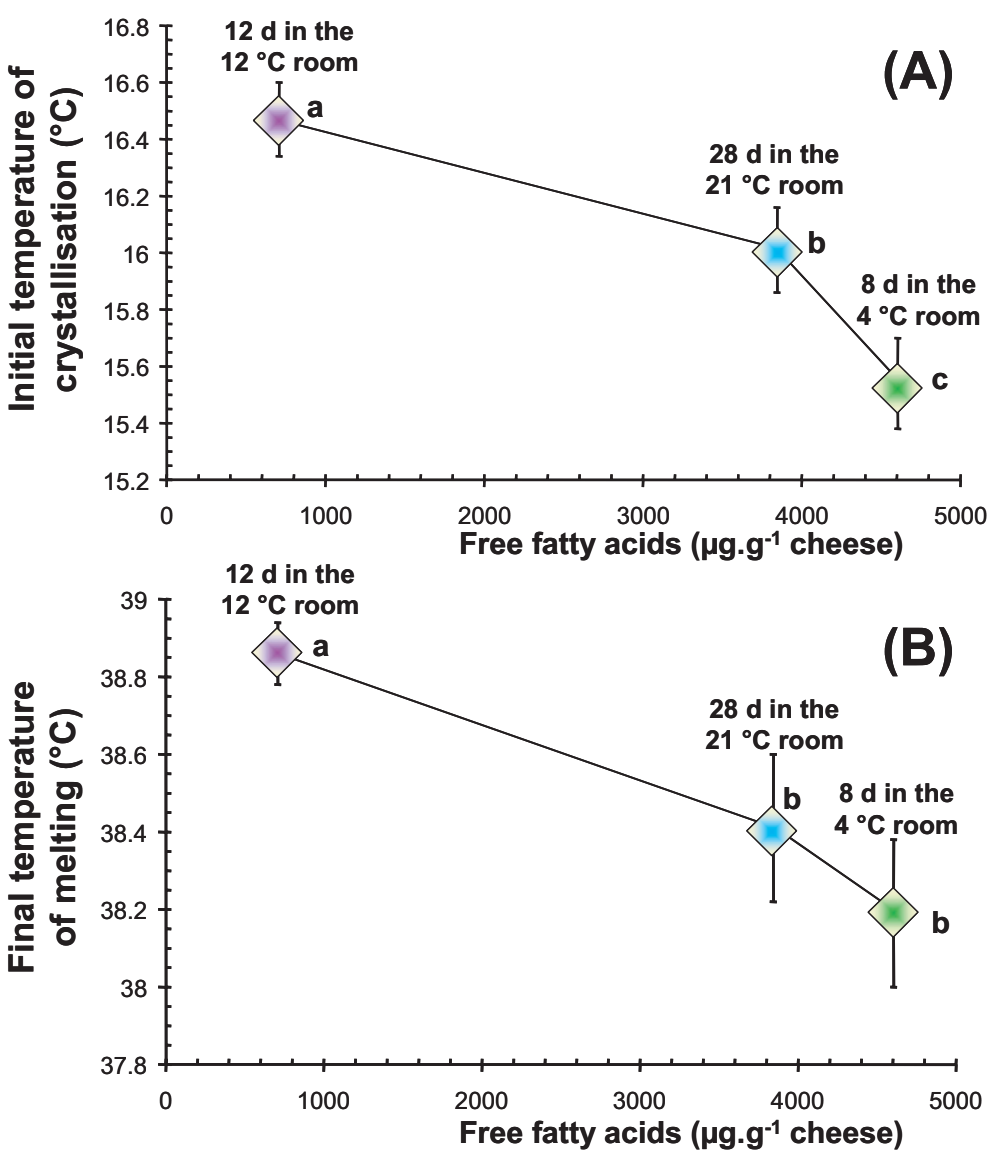

Figure 7. Changes in the thermal properties of fat in Emmental cheese related to lipolysis. (A) Evolution of the initial temperature of crystallisation recorded upon cooling from $60{ }^{\circ} \mathrm{C}$ to $-5{ }^{\circ} \mathrm{C}$ at $2{ }^{\circ} \mathrm{C} \cdot \mathrm{min}^{-1}$. (B) Evolution of the final temperature of melting recorded upon heating from $-5{ }^{\circ} \mathrm{C}$ to $60{ }^{\circ} \mathrm{C}$ at $2{ }^{\circ} \mathrm{C} \cdot \mathrm{min}^{-1}$. The same letters $(\mathrm{a}, \mathrm{b}, \mathrm{c})$ indicate that the values are not significantly different according to the LSD test $(\alpha<0.05)$.

\subsection{Changes in the composition and properties of fat to improve the quality of food products}

\subsubsection{Increase in unsaturated fatty acids}

From a nutritional point of view, milk fat is suspected to take part in the risk of coronary heart disease since it contains cholesterol and 70 to $75 \%$ of saturated fatty acids. Numerous methods have been applied to increase the amount of unsaturated fatty acids, including dietary, chemical and physical (i.e. fractionation and recombination, transesterification). Dietary manipulation by means of cow feeding is a natural solution used to change the composition of fat, while keeping the specific composition and properties of the MFGM. Changing the composition of milk fat to increase the unsaturated fatty acids (UFA; C18:1, C18:2 and C18:3) and particularly the conjugated linoleic acids 


\section{(A) DSC melting curve of fat in Emmental cheese}

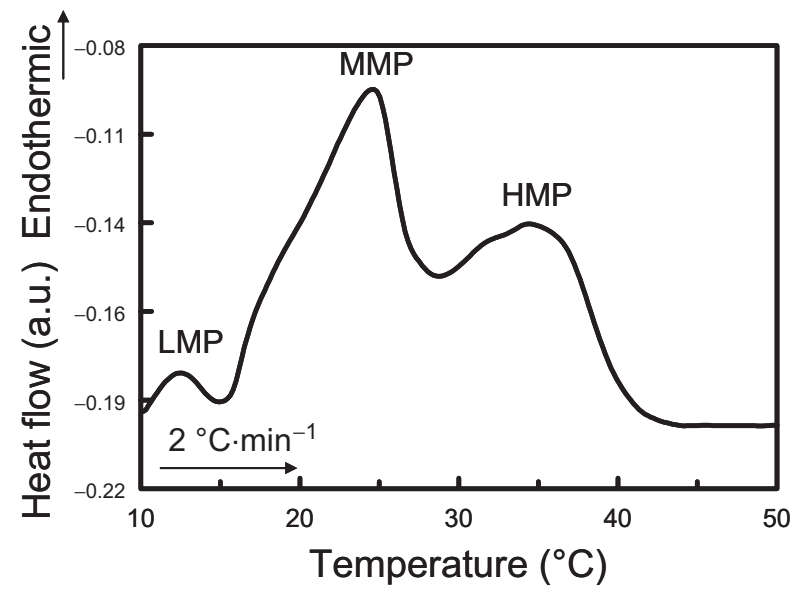

(B) Changes in the solid fat content as a function of temperature

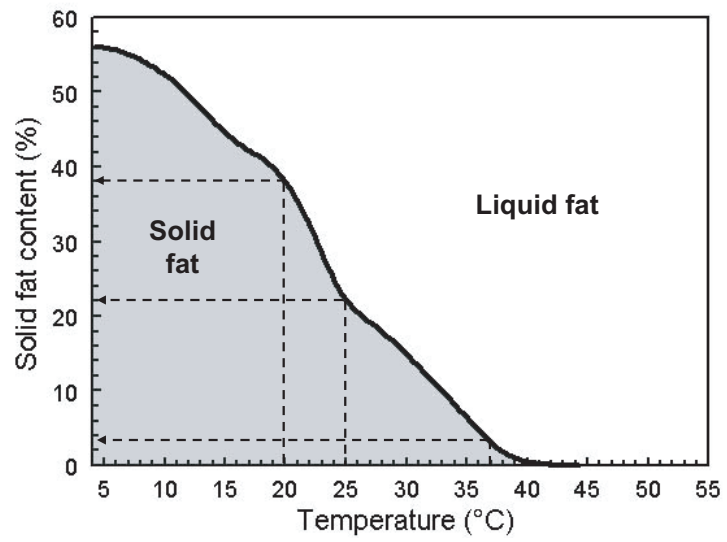

Figure 8. Thermal properties of Emmental cheese at the end of ripening. (A) Melting curve recorded by differential scanning calorimetry (DSC) upon heating from $4{ }^{\circ} \mathrm{C}$ to $60{ }^{\circ} \mathrm{C}$ at $2{ }^{\circ} \mathrm{C} \cdot \mathrm{min}^{-1}$. (B) Solid fat content (\%) determined by direct integration of the DSC melting profile; LMP: low melting point; MMP: middle melting point; HMP: high melting point. Adapted from Lopez et al. [12].

(CLA; mainly the rumenic acid: C18:2 cis 9 trans 11) that would present anticarcinogenic properties can lead to changes in its physical and functional properties and can increase its sensitivity to oxidation, leading to organoleptic defaults.

Recently, our group investigated the influence of changes in milk fat composition using cow feeding (maize silage, linseed and rapeseed) on the thermal and functional properties of butter. Briefly, we changed cow feeding for 9 weeks, using (i) a basic feed with maize silage only (maize silage $(70 \%)+$ complements (cereals, soya)), (ii) maize silage complemented with linseed (maize silage $(70 \%)+$ linseed 
(A) DSC melting curves of butters with different fatty acid compositions

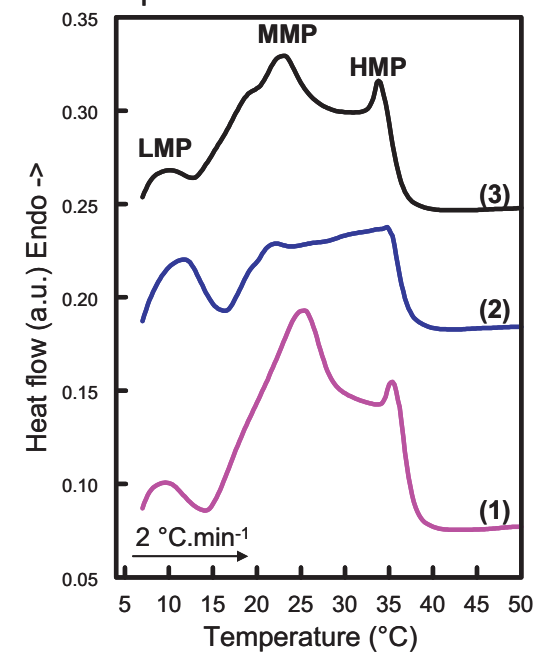

(B) Solid fat content as a function of temperature

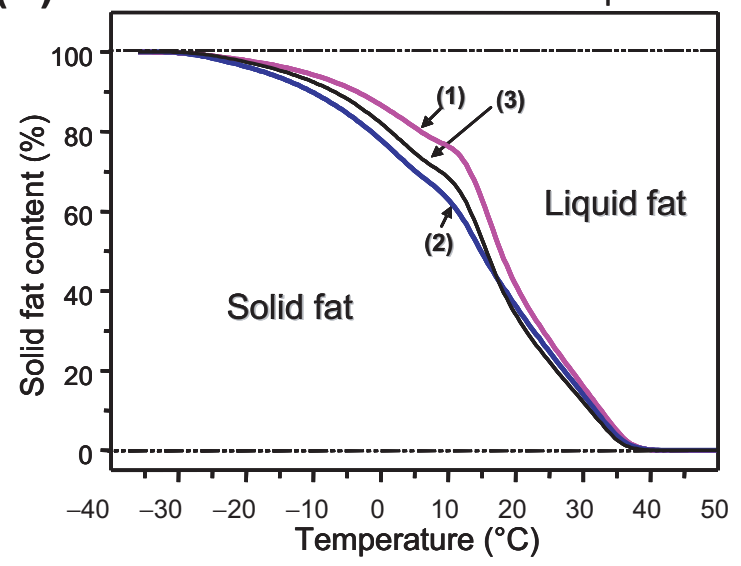

Figure 9. Thermal characteristics of milk fat as a function of its composition, modified by cow feeding. (A) Melting properties of butters recorded by differential scanning calorimetry upon heating at $2{ }^{\circ} \mathrm{C} \cdot \mathrm{min}^{-1}$ from $4{ }^{\circ} \mathrm{C}$ to $60{ }^{\circ} \mathrm{C}$. (B) Solid fat content (\%) determined by direct integration of the DSC melting properties of the fat extracted from butters. (1) Maize silage (70\% ration); (2) maize silage $(70 \%$ ration $)+$ linseed $(6.2 \%$ ration $) ;(3)$ maize silage $(70 \%$ ration $)+$ rapeseed $(6.2 \%$ ration). LMP: low melting point peak; MMP: middle melting point peak; HMP: high melting point peak.

$(6.2 \%)+$ complements (cereals, soya)), and (iii) maize silage complemented with rapeseed (maize silage $(70 \%)+$ rapeseed $(6.2 \%)+$ complements (cereals, soya)). As expected, changing cow feeding affected the composition of milk fat. The amounts of saturated fatty acids were $76.0 \mathrm{~g}$ per $100 \mathrm{~g}$ for maize silage, $70.6 \mathrm{~g}$ per $100 \mathrm{~g}$ for rapeseed and $66.4 \mathrm{~g}$ per $100 \mathrm{~g}$ for linseed. The amounts of UFA were $24.0 \mathrm{~g}$ per $100 \mathrm{~g}$ 
for maize silage, $29.4 \mathrm{~g}$ per $100 \mathrm{~g}$ for rapeseed and $33.6 \mathrm{~g}$ per $100 \mathrm{~g}$ for linseed. Butters were manufactured by an industrial dairy.

Figure 9A shows the DSC melting curves recorded upon heating of butters from $4{ }^{\circ} \mathrm{C}$ to $60{ }^{\circ} \mathrm{C}$ at $2{ }^{\circ} \mathrm{C} \cdot \mathrm{min}^{-1}$. The shape of the DSC curves and the enthalpy of melting correspond to the amount and type of crystals that melt. The temperature of final melting was significantly different between maize silage and the two others $(P<0.001)$. The "maize silage" and "rapeseed" butters showed the 3 characteristic melting peaks: LMP, MMP and HMP. Regarding "linseed" butter, the LMP peak was larger and the MMP peak was quite absent. These peaks correspond to the melting of TG molecules with 1 or 2 unsaturated fatty chains and 1 short-chain fatty acid [7]. Thus, the increase in the UFA content changed the melting properties of the butters. The textural and functional properties of the butters were also evaluated. The hardness of the butters measured at $4{ }^{\circ} \mathrm{C}$ and $12{ }^{\circ} \mathrm{C}$ was in the order linseed $<$ rapeseed $<$ maize silage $(P<0.001)$. The spreadability of the butters, evaluated by trained persons, was in the order linseed $>$ rapeseed $>$ maize silage.

The fat was extracted from the butters to determine the solid fat content as a function of temperature by integrating the DSC melting profile recorded from $-40{ }^{\circ} \mathrm{C}$ to $60{ }^{\circ} \mathrm{C}$ (Fig. 9B). We showed that the richest UFA fat (linseed) had the lowest SFC in all the temperature range. On the contrary, the fat with the lowest level of UFA (maize silage) had the highest SFC in all the temperature range. Thus, the increase in the amount of UFA decreased the SFC, and as a consequence changed the textural and functional properties by decreasing the hardness and increasing the spreadability of the butters.

The functional properties of milk fat are strongly related to its composition and to the amount of fat crystals of various types and sizes that are formed at the temperature of the application. Crystallisation of milk fat affects many properties such as (i) its rheological properties, (ii) the resistance of fat globules to disruption, and (iii) the consistency and mouth-feel of high-fat content products. Furthermore, milk fat crystallisation is essential for the manufacture of whipped products, ice cream and butter.

\subsubsection{Suprastructure of fat}

The organisation of fat in food products results from the properties of fat (mainly its composition), the size of fat globules, the composition of the surface of fat droplets (MFGM or caseins), and the parameters applied during the technological process.

Selecting the size of natural milk fat globules, e.g. enveloped by the MFGM, is a means to change and/or improve the quality of food products. For example, it permits one to control the formation of free fat to modulate the functional properties of cheese (oiling-off and meltability). As shown in our lab, the size of natural fat globules also affects the sensorial properties of food products [18,20]. The composition of the interface, e.g. MFGM, monolayer of phospholipids, caseins, serum proteins or other proteins, changes the interaction of milk fat with the protein matrix in which it is entrapped, leading to specific rheological properties. Changing the parameters of the process can also affect the organisation of fat. For example, changing the temperature, time and pressure during the pressing of curd grains involved during the manufacture of Emmental cheese can affect the amount of free fat, the oiling-off and, as a consequence, the meltability and stretching of cheese (paper in preparation).

From a nutritional point of view, the organisation of fat (globular, i.e. emulsified with various sizes or non-emulsified) in food products and the composition of 
its interface (MFGM or caseins) may be important considering chemical and enzymatic reactions which occur at the interface, such as hydrolysis of triacylglycerols by lipolytic digestive enzymes (gastric + pancreatic) and thus the bioavailability and absorption of fatty acids. Furthermore, we evidenced that solid fat, e.g. crystals, exists in cheese at the temperature of storage and consumption [12]. Further studies need to be performed since the mechanisms involved in the hydrolysis of such solid TG molecules by the digestive lipolytic enzymes have not been investigated and thus are not well known.

\section{CONCLUSION}

The knowledge of the development of the structure of fat, in situ in food products, and the identification of the key step of the process that can drastically change the properties of fat (e.g. pressing during the manufacture of hard-type cheeses) are important for a better comprehension of its functional and sensory properties. We showed that CLSM and DSC are welladapted techniques to explore the organisation of fat and determine the solid fat content in complex food products. Thus, the characterisation of the organisation of fat and the determination of the amount and type of fat crystals will contribute to improving the quality of food products.

From the nutritional and health point of view, increasing the unsaturated fatty acids in milk fat will accord with recommendations for a certain category of persons, sensitive to cardiovascular risks. Moreover, modulating the supramolecular organisation of fat and its environment in food products (viscosity, proteins, minerals, etc.) would allow one (i) to improve well-being after fat-rich meals and satiety (leading to changes in time between meals), and (ii) to change the kinetics of hydrolysis and absorption of lipids in the intestine, to provide physiopathological benefits.

Acknowledgements: B. Robert, B. Camier and J.-Y. Gassi are acknowledged for help during preparation of milk and manufacture of Emmental cheeses. E. Beaucher and M.-B. Maillard are acknowledged for physicochemical analysis. F. Rousseau is acknowledged for laser light scattering measurements.

\section{REFERENCES}

[1] Blonk J.C.G., van Aalst H., Confocal scanning light microscopy in food research, Food Res. Int. 26 (1993) 297-311.

[2] Gresti J., Burgaut M., Maniongui C., Bezard J., Composition of molecular species of triacylglycerols in bovine milk fat, J. Dairy Sci. 76 (1993) 1850-1869.

[3] Gunasekaran S., Ding K., Three-dimensional characteristics of fat globules in cheddar cheese, J. Dairy Sci. 82 (1999) 1890-1896.

[4] Heertje I., van der Vlist P., Blonk J.C.G., Hendrickx H.A.C.M., Brakenhoff G.J., Confocal scanning laser microscopy in food research: some observations, Food Microstruct. 6 (1987) 115-120.

[5] Jensen R.G., Newburg D.S., Bovine milk lipids, in: Jensen R.G. (Ed.) Handbook of milk composition, Academic Press, Inc., New-York, USA, 1995, p. 542.

[6] Keenan T.W., Dylewski D.P., Intracellular origin of milk lipid globules and the nature and structure of the milk lipid globule membrane, in: Fox P.F. (Ed.), Advanced dairy chemistry. Volume 2: Lipids, Chapman \& Hall, London, UK, 1995, p. 89-130.

[7] Lavigne F., Polymorphisme et transitions de phases des triglycérides. Applications aux propriétés thermiques et structurales de la matière grasse laitière anhydre et ses fractions, Ph.D. thesis, Univ. Paris VII, Paris XI and ENSIA (1995).

[8] Lopez C., Focus on the supramolecular structure of milk fat in dairy products, Reprod. Nutr. Dev. 45 (2005) 497-511.

[9] Lopez C., Bourgaux C., Lesieur P., Ollivon M., Crystalline structures formed in cream and anhydrous milk fat at $4{ }^{\circ} \mathrm{C}$, Lait 82 (2002) 317-335.

[10] Lopez C., Bourgaux C., Lesieur P., Bernadou S., Keller G., Ollivon M., Thermal and structural behavior of milk fat. 3. Influence of 
cooling rate and droplet size on cream crystallisation, J. Colloïd Interf. Sci. 254 (2002) 64-78.

[11] Lopez C., Lavigne F., Lesieur P., Bourgaux C., Keller G., Ollivon M., Thermal and structural behavior of anhydrous milk fat. 3 . Influence of cooling rate, J. Dairy Sci. 88 (2005) 511-526.

[12] Lopez C., Briard-Bion V., Camier B., Gassi J.-Y., Milk fat thermal properties and solid fat content in Emmental cheese: a differential scanning calorimetry study, J. Dairy Sci. 89 (2006) 2894-2910.

[13] Lopez C., Bourgaux C., Lesieur P., Riaublanc A., Ollivon M., Milk fat and primary fractions obtained by dry fractionation. 1. Chemical composition and crystallisation properties, Chem. Phys. Lipids 144 (2006) 17-33.

[14] Lopez C., Maillard M.-B., Briard-Bion V., Camier B., Hannon J.A., Lipolysis during ripening of Emmental cheese considering organization of fat and preferential localization of bacteria, J. Agric. Food Chem. 54 (2006) 5855-5867.

[15] Lopez C., Camier B., Gassi J.-Y., Development of the milk fat microstructure during the manufacture and ripening of Emmental cheese observed by confocal laser scanning microscopy, Int. Dairy J. 17 (2007) 235-247.

[16] McPherson A.V., Kitchen B.J., Reviews of the progress of dairy science; the bovine milk fat globule membrane. Its formation, composition, structure, and behaviour in milk and dairy products, J. Dairy Res. 50 (1983) 107 133.

[17] Michalski M.C., Cariou R., Michel F., Garnier C., Native vs. damaged milk fat globules: membrane properties affect the viscoelasticity of milk gels, J. Dairy Sci. 85 (2002) 2451-2461.

[18] Michalski M.C., Gassi J.Y., Famelart M.H., Leconte N., Camier B., Michel F., Briard V., The size of native milk fat globules affects physico-chemical and sensory properties of Camembert cheese, Lait 83 (2003) 131-143.

[19] Michalski M.C., Ollivon M., Briard V., Leconte N., Lopez C., Native fat globules of different sizes selected from raw milk: Thermal and structural behaviour, Chem. Phys. Lipids 132 (2004) 247-261.

[20] Michalski M.C., Camier B., Briard V., Leconte N., Gassi J.Y., Goudédranche H., Michel F., Fauquant J., The size of native milk fat globules affects physico-chemical, and functional properties of Emmental cheese, Lait 84 (2004) 343-358.

[21] Rowney M.K., Roupas P., Hickey M.W., Everett D.W., The effect of compression, stretching, and cooking temperature on free oil formation in mozzarella curd, J. Dairy Sci. 86 (2003) 449-456.

[22] Timms R.E., The phase behavior and polymorphism of milk fat, milk fat fractions, and fully hardened milk fat, Aust. J. Dairy Technol. 35 (1980) 47-53. 